\title{
Bridge Technology with TSH Receptor Chimera for Sensitive Direct Detection of TSH Receptor Antibodies Causing Graves' Disease: Analytical and Clinical Evaluation
}

Authors

Affiliations

\author{
C. U. Frank ${ }^{1 *}$, S. Braeth ${ }^{1 *}$, J. W. Dietrich ${ }^{2}$, D. Wanjura ${ }^{3}$, U. Loos
}

${ }^{1}$ KreLo GmbH Medical Diagnostics, Ulm, Germany

2 Department for Endocrinology and Diabetology, Ruhr University of Bochum, Bochum, Germany ${ }^{3}$ Gemeinschaftspraxis Radiologie \& Nuklearmedizin, Ulm, Germany

\author{
Key words \\ - graves' disease \\ - TSH receptor \\ thyroid stimulating \\ autoantibodies \\ - bridge assay
}

received 14.01.2015 accepted 19.05.2015

\section{Bibliography}

DOI http://dx.doi.org/ 10.1055/s-0035-1554662 Published online:

June 16, 2015

Horm Metab Res 2015; 47: 880-888

(c) Georg Thieme Verlag KG Stuttgart · New York ISSN 0018-5043

Correspondence

Prof. Dr. U. Loos

KreLo GmbH Medical

Diagnostics

Sedanstr. 14

89077 Ulm

Germany

Tel.: +49/731/3980690

382989

Fax: $+49 / 731 / 3980691$

Mobile: +49/172 8032446

ulrich.loos@krelo-med.de

\section{Abstract \\ $\nabla$}

Graves' disease is caused by stimulating autoantibodies against the thyrotropin receptor inducing uncontrolled overproduction of thyroid hormones. A Bridge Assay is presented for direct detection of these thyroid-stimulating immunoglobulins using thyrotropin receptor chimeras. A capture receptor, formed by replacing aa residues $261-370$ of the human thyrotropin receptor with residues 261-329 from rat lutropin/choriogonadotropin receptor and fixed to microtiter plates, binds one arm of the autoantibody. The second arm bridges to the signal receptor constructed from thyrotropin receptor (aa 21-261) and secretory alkaline phosphatase (aa1-519) inducing chemiluminescence. The working range of the assay is from $0.3 \mathrm{IU} / 1$ to $50 \mathrm{IU} / 1$ with a cutoff of $0.54 \mathrm{IU} / 1$ and functional sensitivity of $0.3 \mathrm{IU} / \mathrm{l}$. Sensitivity and specificity are 99.8 and $99.1 \%$, respectively, with a diagnostic accuracy of 0.998 . The low grey zone is from

\section{Nonstandard Abbreviations}

$\nabla$

AITD Auto immune thyroid disease

CRE Cyclic AMP response element

ECD Extracellular domain

EO Endocrine orbitopathy

GD Graves' disease

IQR Interquartile range

LHCG Luteinizing hormone/choriogonadotropin

SEAP Secretory alkaline phosphatase

TRAb Thyroid hormone receptor autoantibody

TRBAb Thyroid hormone receptor-blocking autoantibody

TSH Thyrotropin, thyroid-stimulating hormone

TSHR Thyrotropin receptor, thyroid-stimulating hormone receptor

TSI Thyroid-stimulating immunoglobulin
$0.3-0.54 \mathrm{IU} / 1$. The stimulatory character of the assayed antibodies is shown through a good correlation $\left(r=0.7079, p<10^{-7}\right)$ to serum T4 levels of untreated patients. In Graves' disease, titers are increased in associated eye disease. In 3 hypothyroid patients with sera positive in the thyrotropin receptor competition assay and in the blocking bioassay, antibodies are not detected by the Bridge Assay, while the monoclonal blocking antibody K1-70 was detected. In Hashimoto disease thyrotropin receptor autoantibodies are detected in some patients, but not in goiter. This Bridge Assay delivers good diagnostic accuracy for identification of Graves' disease patients. Its high sensitivity may facilitate early detection of onset, remission, or recurrence of Graves' disease enabling timely adaption of the treatment.

Human genes:

TSHR, Homo sapiens, acc. no. M31774.1

Supporting information for this article is available online at http://www.thieme-connect.de/products

\section{T4 Total thyroxine}

\section{Introduction}

Graves' disease (GD) is an autoimmune disease caused by autoantibodies, which bind to the thyrotropin (TSH) receptor (TSHR) on the surface of thyrocytes, resulting in uncontrolled overproduction of thyroid hormones [1-3]. GD continues to pose a major health risk, with a prevalence of $2-3 \%$ and an incidence of $0.2-0.5 \%$ in iodine sufficient countries, females being affected 10 times more often than males [4-6]. For quantification of TSHR autoantibodies (TRAb) and confirmation of the clinical diagnosis, 2 different types of assay technology are commonly used in laboratory medicine. The most widely practiced assays measure the competition between binding of 
TRAb and TSH $[7,8]$ or a TSHR directed human monoclonal autoantibody [9], respectively, at the TSHR. In contrast to these in vitro TSH competition assays, bioassays measure increased production of cyclic AMP in cellular systems [10-14]. These assays exhibit high specificity but are delicate and laborious. The recently commercialized Thyretain bioassay, which detects the stimulatory activity of TRAb by a chimeric TSHR and a cyclic AMP response element (CRE)-reporter gene and luciferase signaling [12], has been approved by the FDA for use in the clinical laboratory. During revision of this manuscript, the standardization of the Thyretain bioassay [13] as well as a standardized rapid bioassay with detection of thyroid stimulation using cyclic AMP-gated calcium channel and aequorin [14] were published. Most direct assays of TRAb measure the amount of immunoglobulin bound to the TSHR based on immunoprecitation [1518], but they do not achieve high sensitivity and are therefore not used in the clinical laboratory.

We have finally developed an in vitro assay, which directly detects the concentration of TRAb in sera by applying Bridge technology, which was preliminarily reported by us [19] and used by others for TSHR autoantibody studies [20]. By this technology the autoantibody is detected by binding with one arm to a capture receptor on the solid phase and bridging with the other arm to a detection receptor giving a signal. The assay uses chimeric TSHRs detecting thyroid stimulating immunoglobulins (TSI) based on an understanding of the structure of the extracellular domain (ECD) of the TSHR and its interactions with antiTSHR antibodies [21,22]. Studies with mutant receptors indicate that the epitopes for TSI binding are fairly near the N-terminus of the ECD $[12,23]$. Therefore, in our in vitro assay, a chimeric human TSHR, in which aa residues 261-370 were replaced by an equivalent section of the rat LHCG receptor $[23,24]$, was used as capture receptor, and the N-terminus of the TSHR (aa21-261) was used as signal receptor for determination of the autoantibodies.

The main aims of this communication are first to describe the technology of the novel assay and second to demonstrate its effectiveness in diagnosing GD with high sensitivity. In addition, the stimulatory character of the autoantibodies detected by the method had to be examined, all in comparison to a standard competition assay (TRAK human assay).

\section{Materials and Methods \\ $\nabla$ \\ Principle of the Bridge Assay}

The assay is based on the principle that the 2 antigen binding sites of the antibody form a bridge between 2 different TSHR molecules. One arm of the antibody binds to a capture receptor fixed to the surface of a microtiter plate via a coating antibody. The density of the capture receptor is such that its spacing allows only one arm of an antibody molecule to interact with a capture receptor. Once the TRAb molecule has been attached to the capture receptor, a signal receptor with secretory alkaline phosphatase (SEAP) attached is introduced. The signal receptor being in free solution binds to the other arm of the antibody. The amount of signal receptor bound, and thus the amount of antibody bound, is determined by the intensity of enhanced chemiluminescence development by reaction of SEAP with luminescent substrate. The 2 forms of the TSHR and the sequence of events in the assay are illustrated in $\bullet$ Fig. 1.

\section{Plasmids, chemicals, and substances}

The cDNA for human TSHR (pSVL-TSHR plasmid) was kindly provided by Dr. B. Rapoport (Cedars-Sinai Research Institute, Los Angeles, CA, USA). Plasmid pcDNA3-rLHR(B9) was a gift from Dr. D. L. Segaloff (University of Iowa, Iowa City, USA). Other reagents were from the following suppliers: plasmids pIRESneo and pSEAP2-Basic (Clontech, Palo Alto, CA, USA); FuGene transfection reagent (Promega, Madison, OR, USA); DMEM, FCS and G418 (Biochrom, Berlin, Germany); and chemiluminescence substrate (AP-Juice $1 \times$ Low Background, PJK, Kleinblittersdorf, Germany). Interferences were tested with the following substances from BioRad Laboratories Quality Control Products (BioRad, München, Germany): Liquicheck ANA Control Centromere/Homogeneous/ Nucleolar/Speckled Pattern; Lyphocheck Immunoassay Plus Control Trilevel; Liquid Assayed Multiqual Trilevel; Liquicheck Rheumatoid Factor Control Trilevel; and anti-Islet Cell Positive

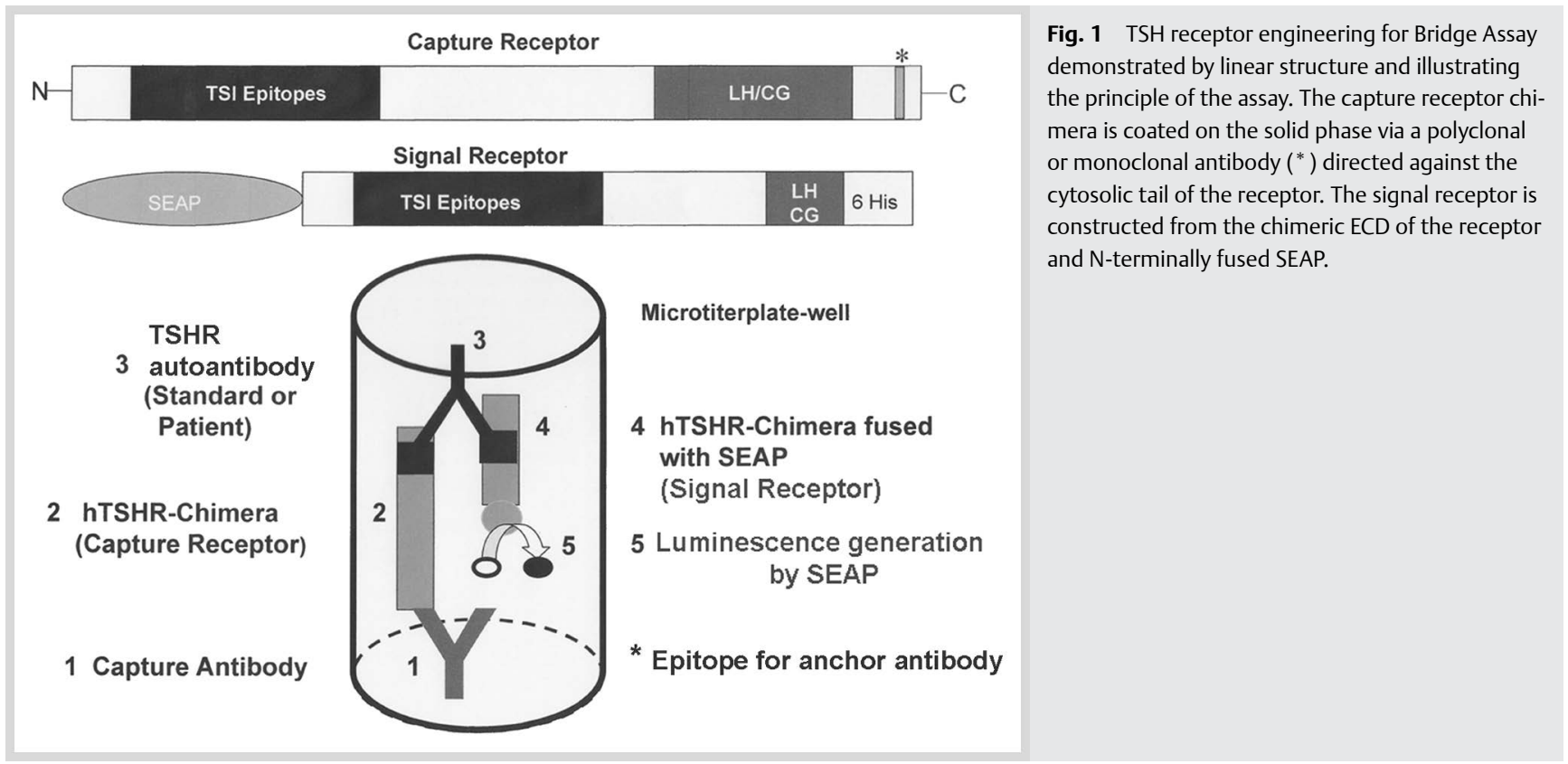


Control. Interference testing for anti-Tg and anti-TPO were performed with anti-Tg Plus Standard S6 and anti-TPO Standards (Thermo Fischer Scientific/Brahms GmbH, Henningsdorf, Germany). Testing for Thyroiditis deQuervain was done with serum from a patient clinically positive for Thyroiditis deQuervain and negative for Graves' disease. Total T4 was measured with a VITROS TT4 assay (Ortho Clinical Diagnostics, Neckargemünd, Germany). TRAb competition assays were determined with the TRAK human assay (Thermo Fischer Scientific/Brahms GmbH, Henningsdorf, Germany). TSHR stimulating or blocking activity was measured with our in-house cAMP response element (CRE) reporter gene bioassay [25].

\section{Construction of plasmids}

The capture receptor was formed by replacing amino acid residues 261-370 of the human TSHR with residues 261-329 from rat LHCG receptor [24], as described previously [16]. For the signal receptor, the DNA sequence encoding amino acids (aa) 21-261 was amplified by PCR and cloned giving pIRESneo-Chimera B(ECD). DNA encoding aa 1-519 for SEAP (pSEAP2-Basic) was amplified by PCR to give the SEAP amplicon, which was then inserted into pIRESneo-Chimera $\mathrm{B}(\mathrm{ECD})$ to give pIRESneo-SEAPChimera $\mathrm{B}(\mathrm{ECD})$ vector.

\section{Generation of receptor-producing cells}

HEK293 cells in DMEM supplemented with $10 \%$ fetal bovine serum were cultivated in a $5 \% \mathrm{CO}_{2}$ atmosphere at $37^{\circ} \mathrm{C}$. Cells were transfected either with pIRESneo-Chimera B or pIRESneoSEAP-Chimera B(ECD) vector using FuGene transfection reagent. Forty-eight hours after transfection, selection was started with $0.8 \mathrm{mg} / \mathrm{ml} \mathrm{G} 418$. Stable high expressing clones were subcloned by limited dilution. Routine cell culture was performed at $37^{\circ} \mathrm{C}$ and $5 \% \mathrm{CO}_{2}$.

\section{Capture receptor}

Cell extract for the capture receptor was prepared by standard methods. Shortly, confluent cells were resuspended in cold PBS $\left(2-8{ }^{\circ} \mathrm{C}\right)$ and centrifuged $\left(10 \mathrm{~min} / 4^{\circ} \mathrm{C} / 4000 \times \mathrm{g}\right)$. The cell pellet was lysed in buffer $(50 \mathrm{mM}$ Tris- $\mathrm{HCl} \mathrm{pH} 8.0,150 \mathrm{mM}$ $\mathrm{NaCl}, 1 \%$ Triton $\mathrm{X} 100$, protease inhibitors) and centrifuged $\left(20 \mathrm{~min} / 4^{\circ} \mathrm{C} / 20000 \times \mathrm{g}\right)$. The supernatant was frozen in nitrogen. Total protein concentration was determined by a DC-ProteinAssay (BioRad) with BSA as standard. A Western blot was carried out to confirm the correct product size. A Bridge Assay was performed with each lot to confirm correct functionality of the protein. To exclude cross-reactivity with other cellular components, cell extracts of nontransfected cells were tested with 20 different stimulating sera or pooled sera.

\section{Signal receptor}

Signal receptor was secreted into the cell culture supernatant. Shortly, $9 \times 10^{6}$ cells were incubated for $24 \mathrm{~h}$ at $27^{\circ} \mathrm{C}$ with $5 \%$ $\mathrm{CO}_{2}$. Supernatant was collected, pooled, and centrifuged for $10 \mathrm{~min}$ at $4000 \times \mathrm{g}$ to remove cells and debris, and frozen at $-196^{\circ} \mathrm{C}$. A Western blot was carried out to confirm the correct product size. The deduced protein size is $85 \mathrm{kDa}$. SEAP activity and binding to TRAb was confirmed in a Bridge Assay for each lot. To exclude cross-reactivity between autoantibodies and SEAP, supernatant of cells transfected with SEAP, but without receptor chimera, was used instead of the signal receptor.

\section{Coating antibody}

An epitope consisting of aa 741-762 from the cytosolic tail of the human TSHR was used to immunize sheep at Labor Dr. Merk und Kollegen (Ochsenhausen, Germany). Antibodies were affinity purified and stored in $50 \%$ glycerol at $-20^{\circ} \mathrm{C}$. Dilution experiments were carried out to find the optimal coating antibody concentration.

\section{Bioassay of stimulating or blocking TSH receptor autoantibodies}

Stimulatory activity of autoantibodies was measured as presented at the International Thyroid Congress 2010 in Paris [25]

(Fig. 1S). Blocking activity was measured by inhibition of TSHR stimulation with $0.5 \mathrm{U} / \mathrm{l}$ bovine $\mathrm{TSH}$, added directly before addition of serum.

\section{Patient samples}

Patients were referred because of thyroid problems or suspected or verified GD according to usual clinical practice in 2 thyroid clinics from surrounding noniodine-deficient regions with up to 2 million inhabitants. For ROC analysis, inclusion criteria for the diagnosis of GD, following the guidelines of the ATA and AACC [26], were: clinical and biochemical hyperthyroidism, exclusion of toxic adenoma, toxic multinodular goiter or subacute thyroiditis, hypoechogenity and hypervascularization in ultrasound. Waste serum of blood withdrawal from these patients was collected and frozen at $-20^{\circ} \mathrm{C}$. Ethical approval was obtained from the Regierungspräsidium Stuttgart.

Altogether 599 samples, collected from 2 local clinics referred with suspected or proven GD, were used for ROC analysis, of which 274 turned out to be clinically GD positive and 325 GD negative. Among the GD positive samples, 248 were from patients in treatment at the time of blood withdrawal and 27 were from untreated patients; 24 samples were from patients with active endocrine orbitopathy (EO) classified according to the EUGOGO guidelines [27]. Samples from 48 euthyroid patients with goiter diagnosed by ultrasound and autoimmune thyreopathy excluded were collected from one local clinic. Additionally 57 patients with Hashimoto thyroiditis were collected by usual inclusion criteria (clinical and biochemical hypothyroidism, typical thyroid imaging by ultrasound, elevated anti-TPO). These patients were transferred to the thyroid clinic from a large region of southern Germany. A separate retrospective collection of 42 samples from untreated GD patients was used for comparison of Bridge Assay results with T4 values. Three patients with hypothyroidism and positive TRAb (TRAK human) were found among hundreds of patients with thyroid problems during referral to 2 thyroid clinics.

\section{Assay procedure}

A 96-well microtiter plate was coated with $100 \mu$ l of coating antibody $(10 \mu \mathrm{g} / \mathrm{ml}$ in $100 \mathrm{mM}$ carbonate buffer $\mathrm{pH} 9.6)$, followed by overnight incubation at $4^{\circ} \mathrm{C}$ and washing with assay buffer $(0.1 \% \mathrm{v} / \mathrm{v}$ Triton X-100, $100 \mathrm{mM} \mathrm{NaCl}, 50 \mathrm{mM}$ Tris- $\mathrm{HCl} \mathrm{pH}$ 8.0). After blocking for $1 \mathrm{~h}$ at $37^{\circ} \mathrm{C}$ with $300 \mu$ blocking buffer ( $5 \%$ milk powder and $5 \%$ glucose in $100 \mathrm{mM}$ carbonate buffer $\mathrm{pH}$ 9.6), the liquid was discarded and $100 \mu \mathrm{l}$ of the capture receptor cell extract were added ( $500 \mu \mathrm{g} / \mathrm{ml}$ in assay buffer), followed by incubation at room temperature for $1 \mathrm{~h}$ with shaking ( $300 \mathrm{rpm}$ ) and a wash step with assay buffer. Calibrators, controls or samples $(50 \mu \mathrm{l})$ and assay buffer $(50 \mu \mathrm{l})$ were added, and the plate was incubated at room temperature for $90 \mathrm{~min}$ with shaking 
(300 rpm). After another wash step with assay buffer, the signal receptor (10 $\mu$ l diluted 1:10 with assay buffer) was added and the plate maintained at $37^{\circ} \mathrm{C}$ with shaking $(300 \mathrm{rpm})$ for $30 \mathrm{~min}$, followed by a wash step and incubation with chemoluminescence substrate $(100 \mu \mathrm{l})$. Light emission was measured with a CentroLIA LB 961 Luminometer (Berthold Technologies, Bad Wildbad, Germany). Results were calculated as IU/l.

\section{Standard serum}

The serum used to generate standard curves was WHO standard 90/672 for thyroid stimulating autoantibodies (UK National Institute for Standards and Controls). We did not change to the new WHO standard 08/204 to obtain comparability to results created before its availability.

\section{Statistical analysis}

Results of the Bridge Assay were calculated as IU/I with WinGlow software (Berthold Technologies, Bad Wildbad, Germany). ROC analysis was used for evaluation of diagnostic accuracy. Intraund inter-assay CVs were calculated following NCCLS guideline EP5 with 2 replicates per run and one run per day for at least 30 days [28]. Calculations were performed with custom S-scripts for the statistical environment R 2.10 [29]. A grey zone was calculated using values with an inter-assay CV between 15 and $\leq 20 \%$. For the TRAK human assay, grey zone was defined by the manufacturer between $1.0 \mathrm{IU} / \mathrm{l}$ and $1.5 \mathrm{IU} / \mathrm{l}$.

\section{Results}

$\nabla$

\section{Analytical characteristics of the Bridge Assay}

Verification of the plasmids has been presented previously [15]. Successful construction of the assay is illustrated by a typical standard curve as shown in $\odot$ Fig. 2a. Standards ranging from $0.1 \mathrm{IU} / \mathrm{l}$ to $50.0 \mathrm{IU} / \mathrm{l}$ were made using the WHO standard 90/672 for thyroid-stimulating autoantibodies and GD negative serum for $0.0 \mathrm{IU} / \mathrm{l}$ (zero calibrator).

To exclude cross-reactivity with other cellular components, extracts of nontransfected cells were tested with 20 different GD patient sera or pooled sera. None of these sera gave a signal higher than background. No cross-reactivity could be detected between autoantibodies and SEAP alone (data not shown).

The effective working range was from $0.3 \mathrm{IU} / \mathrm{l}$ up to $50 \mathrm{IU} / \mathrm{l}$, using only values with inter-assay CVs lower than $20 \%$. High precision is shown by a mean within-run CV of $5.1 \%$ for values covering the working range. Details for the intra- and inter-assay CVs over the range of standards are shown in $\boldsymbol{0} \mathbf{~ F i g . ~} \mathbf{2 b}$; results are from 50 independent runs (except $0.6 \mathrm{IU} / \mathrm{l}, 35$ runs) with duplicate samples. Multiple dilution experiments with patient sera or pooled sera, showing antibody titers exceeding the measuring range up to $178 \mathrm{IU} / \mathrm{l}$, did not show any hook effect as shown in a typical example in Fig. 3S A. Results of the same dilutions measured with TRAb competition assay also show no hook effect but with pronounced flattening of the curve.

\section{Interference testing}

No interference was found for nonthyroidal autoimmune disease, and for endogenous metabolites and exogenous compounds (pharmaceuticals) in the panel of BioRad Laboratories Quality Control Products and thyroid autoantibodies of Thermo Fischer Scientific/Brahms GmbH.

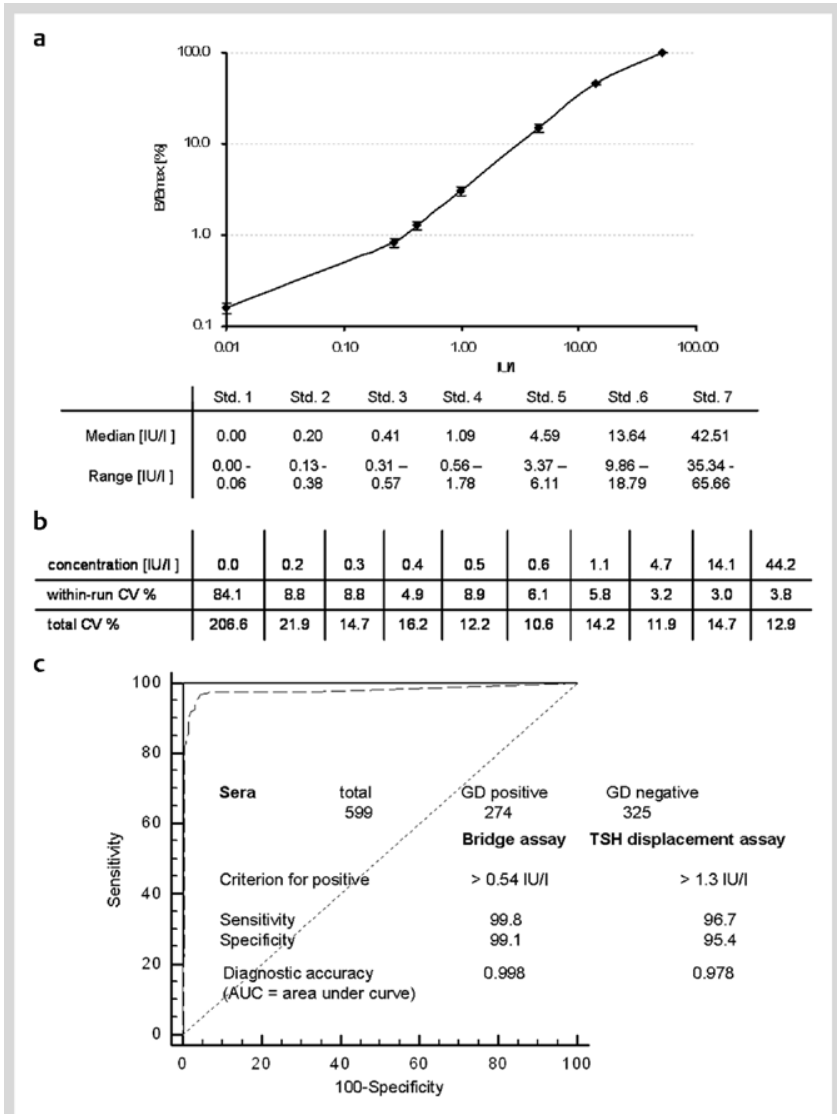

Fig. 2 Bridge Assay standard curve and ROC analysis. a Standard curve (mean of 20 curves), plotted as percentages of bound autoantibodies relative to binding of maximum calibrator (\% B/Bmax) vs. standard concentrations (IU/I), showing $95 \%$ confidence limits, supplemented by median values and range. $\mathbf{b}$ Intra- and interassay $\mathrm{CV}$ ranging from zero calibrator up to $50 \mathrm{IU} / \mathrm{l}$. c Comparative ROC-analysis for Bridge Assay and TRAb (TRAK human assay) competition assay showing higher diagnostic accuracy and lower cutoff for Bridge Assay.

\section{Clinical characteristics of the Bridge Assay and comparison with competition assay GD and health}

Serum samples from 599 individuals, GD positive $(\mathrm{n}=274)$ or GD negative $(n=325)$, were used to assess the clinical characteristics of the Bridge Assay. $\odot$ Fig. 3a illustrates results for GD negative (median $0.01 \mathrm{IU} / \mathrm{l}$; range undetectable to $0.49 \mathrm{IU} / \mathrm{l}$ ) and GD positive samples (median $4.42 \mathrm{IU} / \mathrm{l}$; range $0.54 \mathrm{IU} / \mathrm{l}$ to $50 \mathrm{IU} / \mathrm{l}$ ). There were no false positive and no false negative results.

For the same patient samples, a TRAb competition assay (TRAK human) was performed ( $\bullet$ Fig. 3b). The working range of the latter is from $1.0 \mathrm{IU} / \mathrm{l}$ to $40 \mathrm{IU} / \mathrm{l}$. Median and range for the TRAb competition assay for GD negative samples were $0.0 \mathrm{IU} / \mathrm{l}$ and undetectable up to $18.8 \mathrm{IU} / \mathrm{l}$, respectively, and for GD positive samples $6.3 \mathrm{IU} / \mathrm{l}$ and $0.0 \mathrm{IU} / \mathrm{l}$ to $40 \mathrm{IU} / \mathrm{l}$, respectively. The criterion for positivity in the Bridge Assay, calculated by ROC analysis, was $>0.54 \mathrm{IU} / \mathrm{l}$, with a grey zone of $0.3-0.54 \mathrm{IU} / \mathrm{l}$, and in the TRAb competition assay $>1.3 \mathrm{IU} / \mathrm{l}$, with a grey zone of $1.0-1.5 \mathrm{IU} / \mathrm{l}$ according to manufacturer's data. The sensitivity and specificity of the Bridge Assay were 99.8 and $99.1 \%$, respectively; the corresponding results for the TRAb competition assay were 96.7 and $95.4 \%$. The diagnostic accuracy of the 2 assays were 0.998 (Bridge Assay) and 0.978 (TRAb competition assay). These 


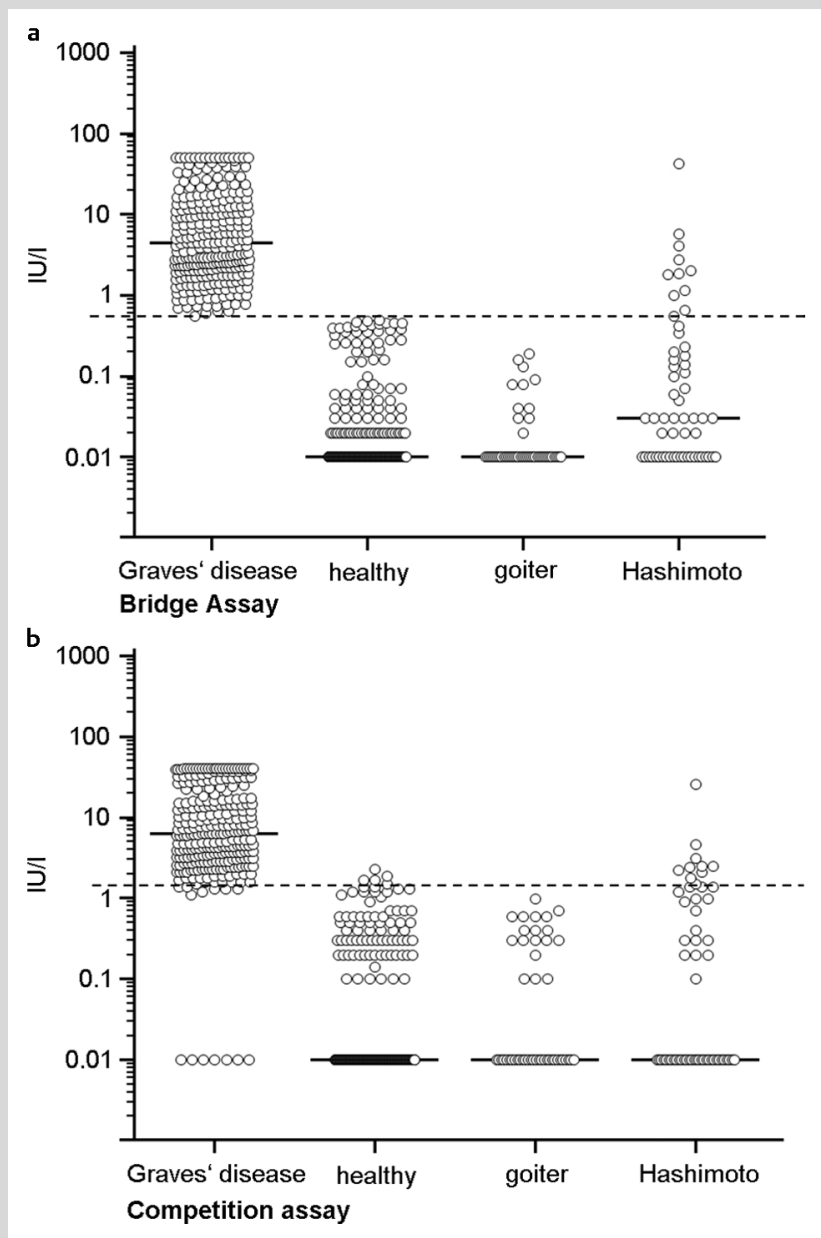

Fig. 3 Scattergrams with patient groups; samples from GD patients (274), apparently healthy subjects (265), patients with goiter (48), and Hashimoto's thyreoditis (58). Bridge Assay a For GD positive samples the median is $4.39 \mathrm{IU} / \mathrm{I}(\mathrm{IQR} 10.11 \mathrm{IU} / \mathrm{I}), 0.01 \mathrm{IU} / \mathrm{I}$ for samples from apparently healthy subjects (IQR $0.01 \mathrm{IU} / \mathrm{I})$ and from patients with goiter (IQR $0.00 \mathrm{IU} / \mathrm{I})$, and $0.03 \mathrm{IU} / \mathrm{I}$ for samples from the Hashimoto group (IQR $0.18 \mathrm{IU} / \mathrm{I})$. TRAb competition assay (TRAK human). b The median is 6.3 IU/I for GD positive samples (IQR 13.1 IU/I), $0.01 \mathrm{IU} / \mathrm{I}$ for samples from apparently healthy subjects (IQR $0.19 \mathrm{IU} / \mathrm{I})$, from patients with goiter (IQR $0.29 \mathrm{IU} / \mathrm{I}$ ) and from the Hashimoto group (IQR 0.09IU/I). The black line indicates the median, the dotted line refers to the cutoff of the respective assay.

results are illustrated in the ROC plot ( $\odot$ Fig. 2 c). There were 10 false positive and 7 false negative results in the TRAb competition assay; there were no false positive and no false negative results in the Bridge Assay. In the Bridge Assay 26 sera were in the grey zone. All but one of these sera were diagnosed as GD negative, the only clinically GD-positive serum had a result of $0.54 \mathrm{IU} / \mathrm{l}$ in the Bridge Assay, whereas this serum had a value of $1.4 \mathrm{IU} / \mathrm{l}$ in the TRAb competition assay. In contrast, there were 19 sera in the grey zone of the TRAb competition assay, with 7 of them clinically diagnosed GD positive and 12 as GD negative.

- Table 1 shows results where the Bridge Assay and TRAb competition assay results diverged: In sera from 13 euthyroid patients, the competition assay identified values within the grey zone (1.0-1.5 IU/l; set by the manufacturer), whereas the Bridge Assay results were clearly below its grey zone of $0.3-0.54 \mathrm{IU} / \mathrm{l}$, except for one sample with a value near the lower limit of the grey zone. On the other hand, in sera from $9 \mathrm{GD}$ positive patients
Table 1 Comparison of Bridge Assay and TRAb values in the very low range. ${ }^{\S}$

\begin{tabular}{|c|c|c|c|}
\hline Sample & $\begin{array}{l}\text { TRAk human } \\
\text { (IU/I) }\end{array}$ & $\begin{array}{l}\text { Bridge assay } \\
\text { (IU/I) }\end{array}$ & Clinical status \\
\hline \multicolumn{4}{|c|}{$\begin{array}{l}\text { Comparison for Bridge Assay results with those within the grey zone } \\
\text { of the TRAK }\end{array}$} \\
\hline R0527 & 1.0 & 0.0 & \multirow{13}{*}{$\begin{array}{l}\text { Clinically normal } \\
\text { (Results from the Bridge } \\
\text { assay are within below its } \\
\text { grey zone) }\end{array}$} \\
\hline R4565 & 1.0 & $0.34^{*}$ & \\
\hline R4595 & 1.1 & 0.0 & \\
\hline R4825 & 1.1 & 0.0 & \\
\hline R5090 & 1.1 & 0.0 & \\
\hline R4808 & 1.2 & 0.0 & \\
\hline R4874 & 1.2 & 0.0 & \\
\hline B0010 & 1.2 & 0.0 & \\
\hline B0024 & 1.2 & 0.26 & \\
\hline В0099 & 1.3 & 0.26 & \\
\hline B0294 & 1.4 & 0.0 & \\
\hline B0003 & 1.4 & 0.15 & \\
\hline R8025 & 1.5 & 0.0 & \\
\hline R2869 & 1.0 & 0.89 & \multirow{9}{*}{$\begin{array}{l}\text { Clinically GD positive } \\
\text { (Results from the Bridge } \\
\text { assay are in the positive } \\
\text { range) }\end{array}$} \\
\hline B0229 & 1.0 & 1.23 & \\
\hline R7645 & 1.0 & 2.30 & \\
\hline B0001 & 1.1 & 2.35 & \\
\hline B0070 & 1.2 & 1.85 & \\
\hline B0169 & 1.3 & 0.78 & \\
\hline B0039 & 1.3 & 1.23 & \\
\hline B0134 & 1.5 & 1.47 & \\
\hline B0187 & 1.5 & 1.65 & \\
\hline \multicolumn{4}{|c|}{$\begin{array}{l}\text { Comparison of results of serum from patients with TSHR blocking } \\
\text { antibodies }\end{array}$} \\
\hline PL02 & 18.8 & 0.0 & \multirow{3}{*}{$\begin{array}{l}\text { Clinically hypothyroid, } \\
\text { treated with I-thyroxine }\end{array}$} \\
\hline A001a & 13.0 & 0.0 & \\
\hline A002 & 7.0 & 0.63 & \\
\hline \multicolumn{4}{|c|}{ Comparison of results using a commercial TSHR blocking mAb } \\
\hline \multirow[t]{2}{*}{ K1-70 } & $\sim 3.5$ & $1.53^{\mathrm{a}}$ & \\
\hline & $<2$ & $0.24^{\mathrm{b}}$ & \\
\hline
\end{tabular}

$\S$ Samples from clinically normal and clinically positive patients with grey zone TRAb-values (1.0-1.5 IU/I, manufacturer's information) can be assigned with values clearly above or below the cutoff of the Bridge Assay. Samples from clinically hypothyroid patients have positive TRAb values, but have very low or negative Bridge Assay values. A commercial monoclonal antibody was positive in the TRAb assay and with lower values in the Bridge Assay

${ }^{*}$ Close to the lower limit of the Bridge assay grey zone

${ }^{a}$ At $20 \mathrm{ng} / \mathrm{ml}$ in normal human serum

${ }^{\mathrm{b}}$ At $4 \mathrm{ng} / \mathrm{ml}$ in normal human serum

the TRAb competition assay detected values in the grey zone, whereas the Bridge Assay results were above its cutoff.

\section{Thyroid disease other than GD}

TRAb in serum from patients with goiter $(n=48)$ was undetectable, resulting in a specificity of $100 \%$ for both the Bridge Assay and the competition assay, while in samples of Hashimoto patients $(n=57)$ specificity was $82.5 \%$ for Bridge Assay and $86.0 \%$ for competition assay ( $\bullet$ Fig. 3 ).

\section{The presence of TSHR blocking antibodies}

In sera of 3 patients exhibiting clinical and biochemical hypothyroidism, using the TRAb competition assay, the presence of TRAb was within the range seen in GD patients. In contrast, using the Bridge Assay only one patient had a level within the GD low range ( $\bullet$ Table 1 ). Sera of 2 of these patients, who were suspected of possessing TSHR blocking antibodies, did not exert any stimulation in our bioassay [25], but blocked TSH stimula- 


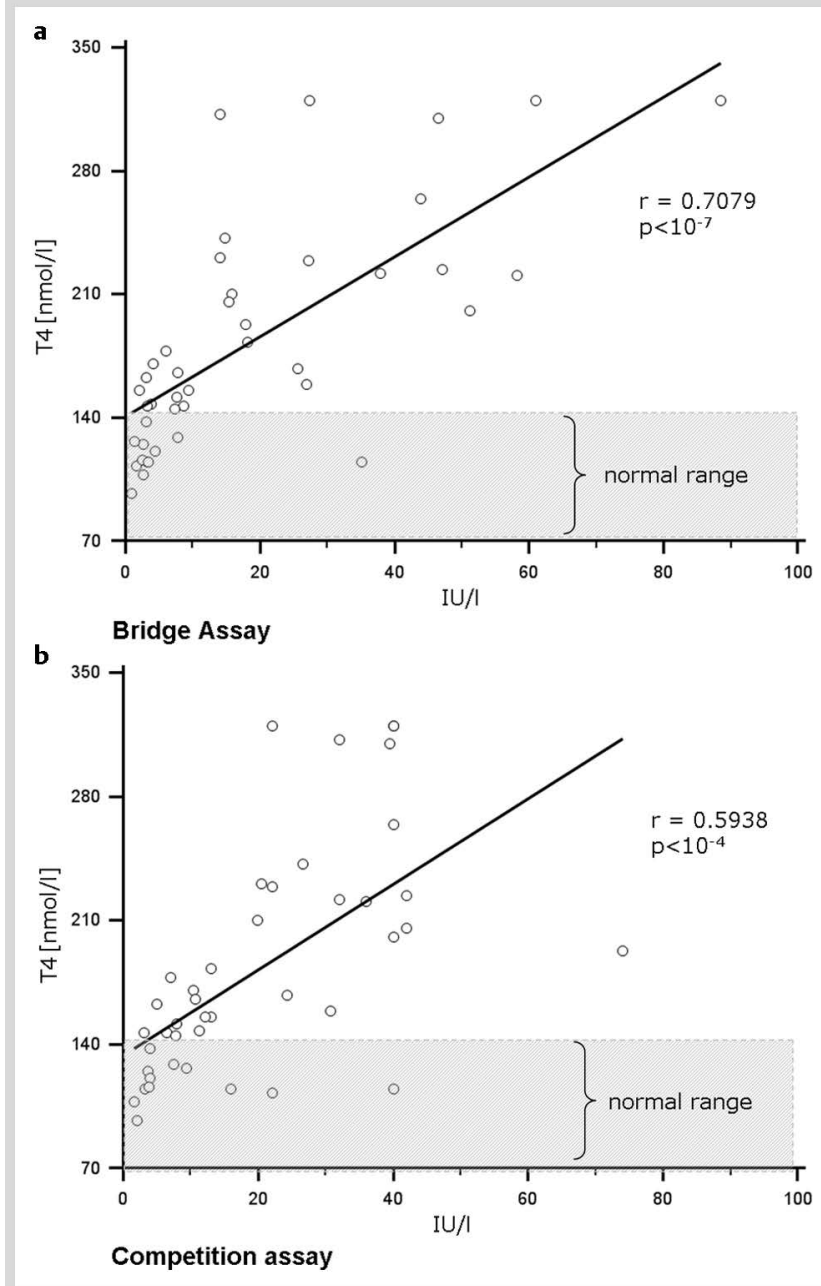

Fig. 4 Correlation of anti-TSHR titers with results of T4 serum concentrations representing the main thyroid secretion product; retrospective collection of 42 samples from untreated GD patients. a Correlation of Bridge Assay results with $\mathrm{T} 4$ values showing linear correlation between titers in the Bridge Assay and T4 with $r=0.7079\left(p<10^{-7}\right)$. b Correlation of competition assay with $\mathrm{T} 4$ values illustrating linear correlation between TRAb and T4 with $r=0.5938\left(p<10^{-4}\right)$.

tion by 37 and $22 \%$, respectively. This qualitative in house bioassay measures SEAP secreted after being cleaved from CRE-reporter gene and secreted into the cell culture medium. No serum was left from the third patient for assaying blocking activity.

It has to be noted that the commercially available monoclonal blocking antibody, K1-70, showed results of 1.53 and $0.24 \mathrm{IU} / \mathrm{l}$ in the Bridge Assay at a concentration of 20 and $4 \mathrm{ng} / \mathrm{ml}$, respectively. These concentrations correlate with estimations of the range of total TRAb concentration in patients' sera [30,31].

\section{Correlation with serum T4}

The correlation between TRAb levels results from 42 untreated patients and the corresponding T4 serum values is shown in Fig. 4. The linear correlation of results using the Bridge assay had values of $\mathrm{r}^{2}=0.5011 ; \mathrm{r}=0.7079\left(\mathrm{p}<10^{-7}\right)$, as compared with $\mathrm{r}^{2}=0.3526 ; \mathrm{r}=0.5938\left(\mathrm{p}<10^{-4}\right)$ in the competition assay.
Table 2 Bridge Assay and endocrine orbitopathy. ${ }^{a}$

\begin{tabular}{|llll} 
& Healthy & GD & GD with active EO \\
\hline Number & 265 & 151 & 24 \\
\hline Mean (IU/I) & 0.07 & 6.65 & 29.64 \\
Median (IU/I) & 0.01 & 2.96 & 22.77 \\
$t$-Test & Healthy - GD $p<10^{-13}$ & \\
& Healthy - GD with active EO $p<10^{-6}$ \\
& GD - GD with active EO $p<10^{-8}$ & \\
&
\end{tabular}

${ }^{a}$ Bridge Assay results of 3 distinct groups of patients recruited from the collection of subjects used for ROC analysis: patients with GD without active or inactive endocrine orbitopathy (EO, $n=151)$, patients with $G D$ and active $E O(n=24)$, and healthy subjects without any thyroid disease $(n=265)$. Patients with $G D$ and inactive EO $(n=78)$ were excluded. The $t$-test shows highly significant differences

\section{Relation of Bridge Assay results and endocrine orbitopathy}

Among the 274 GD positive sera, the Bridge Assay results of a subgroup of 24 GD patients with active EO were compared with the results of 151 GD patients without EO. A subgroup of 265 GD-negative sera without Hashimoto or other thyroid diseases served as control group. $\odot$ Table 2 shows a highly significant difference ( $p<0.001$ ), with a mean of $29.64 \mathrm{IU} / 1$ (median $22.77 \mathrm{IU} / \mathrm{l}$ ) in sera from patients with active EO vs. a mean of $6.65 \mathrm{IU} / \mathrm{l}$ (median 2.96 IU/1) in sera from patients with GD but without eye disease. For the control group, the mean was 0.06 IU/1 (median $0.01 \mathrm{IU} / 1)$.

\section{Discussion}

$\nabla$

\section{Technical data}

The measurement of thyroid-stimulating autoantibodies (TSI) described herein is in agreement with former and recent studies, which show that TSI bind to the N-terminus of the extracellular domain (ECD) of the TSHR and induce thyroid stimulation $[11,12,23]$. Thus, the Bridge Assay uses 2 TSHR chimeras, one, the capture receptor, with an intact $\mathrm{N}$-terminus and having aa residues 261-370 near the C-terminus of the ECD substituted with a corresponding section from the LHCG receptor, and second, the signal receptor consisting of aa 21-261, thus, of the N-terminus of the ECD of the TSHR fused with SEAP as chemiluminescence monitor. The novelty of our Bridge Assay is the technology of TRAb measurement enabling double direct epitope recognition of autoantibodies by using these genetically engineered chimeric human TSHRs ( $\bullet$ Fig. 1 ). The capture TSHR, extracted from stable transfected cell lines, is anchored by a coating antibody to a solid phase to bind only one arm of the antibody. This is guaranteed by spacing of the capture TSHRs achieved by experimentally adjusted dilution of coating antibody. The second chimeric signal receptor fused with SEAP binds to the free second arm of the antibody and gives a signal for the quantification of the antibodies. The signal receptor is secreted into the cell culture medium and needs no further purification and consequently allows accurate detection of TRAb achieved by enhanced chemiluminescence signaling.

\section{Analytical data}

As reported herein, by comparison with the widely accepted TRAb competition assay (TRAK human), this novel technology acting through double direct detection of TRAb confers increased sensitivity (99.8 vs. 96.7\%) and specificity (99.1 vs. 
$95.4 \%)$ as well as a very low cut-off of 0.54 vs. $1.53 \mathrm{IU} / \mathrm{l}$ and a low and small grey zone $(0.3-0.54 \mathrm{IU} / \mathrm{l}$ vs. $1.0-1.5 \mathrm{IU} / 1)$. This also explains the lower functional sensitivity of the Bridge Assay Fig. 2S. Furthermore, a broad working range from $0.54-50 \mathrm{IU} / \mathrm{l}$ is given and serial dilution curves show a slope of one and beyond this range higher concentration of TRAb are without any hook effect.

\section{Clinical evaluation}

The Bridge Assay differentiates low TRAb values in GD patients from individuals without GD ( $\odot$ Fig. 3). The grey zone from the $2^{\text {nd }}$ generation TRAb assay can be resolved. These characteristics will allow early diagnosis of onset and remission as well as relapse of disease. Early treatment of GD ameliorates the severity of the course of the disease [32] by avoiding an increase of the TSHR autoantibody titer and consequently worsening of hyperthyroidism. According to Eckstein et al. [33], there is an increasing risk of induction of "frightened face" endocrine orbitopathy (EO), when the titer of TRAb increases. Our studies clearly support these findings, demonstrating increased antibody titers in active EO ( $\odot$ Table 2 ).

The Bridge Assay showed excellent variance data and high agreement with the diagnosis of GD (see ROC analysis). Furthermore, in untreated GD patients the antibody titers measured by the Bridge Assay correlated significantly with the main thyroid secretion product represented by serum T4 levels, whereas the $2^{\text {nd }}$ generation TRAb assay showed a relatively low correlation (๑ Fig. 4). Comparatively, in untreated GD patients the Thyretain assay using similar TSHR chimera as the presented Bridge Assay (with nearly identical aa exchange) was reported to exhibit a higher correlation to fT4 serum levels than did the bioassay using wild-type TSHR [12]. The Thyretain bioassay by its chimera binds TRAbs, which exhibited stimulation of cAMP production more effectively than its version using wildtype TSHR [12]. Altogether, these data strongly suggest that the thyroid antibodies measured by the Bridge Assay in fact are thyroidstimulating antibodies.

\section{Possible interferences with TSH receptor blocking antibodies (TRBAb)}

We did not find binding activity in the sera of 3 patients, who were positive in the TRAK human assay and exhibited clinical and biochemical hypothyroidism. This discrepancy is explained by the existence of TRBAb, as shown by inhibition of TSH stimulation by our in house CRE reporter gene bioassay [25] in 2 of 3 of these patient sera. Nevertheless, the commercial K1-70 antibody [34,35], a human monoclonal blocking antibody, exhibited binding activity in our assay, but considerably less than in the TRAK human assay ( $\bullet$ Table 1 ). The Thyretain bioassay was reported as capable of measuring inhibition of TSH-stimulated cyclic AMP production for the detection of TRBAb in some patients with AITD [36]. On the other hand, serum samples of 22 TRAb (TRAK human) positive patients with hypothyroidism and blocking activity in the bioassay the majority (19) showed binding at the C-terminus of the TSHR ECD having the N-terminal part (aa 8-165) replaced by LHCG receptor residues and being coated to tubes for measurement of TRAb by TSH competition [37]. There are several further reports on TRBAb binding at the C-terminus as well as at the N-terminus of the TSHR ECD, which findings may thus be explained by epitope heterogeneity of TRBAb binding [20,37-40]. None of the studies provided a recruitment regimen, which would allow to estimate the preva- lence of TRBAb positive patients. The prevalence of patients with TRBAb seems to be very low. Our experience with 2 clinics is that less than one of such patients occurs among 100 of GD patients recruited by usual transferal practice. Concerning stimulating TRAb, there is unanimous opinion that they bind exclusively at the N-terminus of the TSHR ECD $[12,20,40,41]$.

\section{Other thyroid diseases}

Patients with non-autoimmune euthyroid diffuse, uni- or multinodular goiter are not recognized by our Bridge Assay. This fact is of importance because goiter is a very frequent thyroid disease. However, in serum of 57 hypothyroid patients with Hashimoto disease high TPO Ab titers are accompanied by moderately elevated titers of TRAb measured by our Bridge Assay as well as by the TRAK human assay. These data are in agreement with the literature [42] reporting increased sensitivity accompanied by loss of specificity when detecting TRAb titers in hypothyroid Hashimoto disease.

\section{Perspectives}

Knowledge of the TRAb titers measured by the Bridge Assay at onset as well as during monitoring of the disease under treatment may contribute to the interesting observations on the prediction of the course and prognosis of the disease $[43,44]$. Furthermore, the Bridge Assay may assist for elucidating the character of elevated TRAb values during the course of methimazole treatment and in remission, which are suspected of having changed biological activity [45]. Concerning the binding site of blocking TRAb, extensive studies with many TRBAb harboring patients will be necessary to show by epidemiological planned recruitment the differentiation and relation of the different binding locations at the TSHR ECD.

\section{Conclusion}

$\nabla$

The technology of the Bridge Assay presented here leads to good accuracy for detection of thyroid stimulating immunoglobulins. The high sensitivity allows early diagnosis and therefore timely treatment of GD, thus avoiding aggravation and complications of this disease. TRAb measured by the Bridge Assay using hybrid TSHR for capturing and quantifying TRAb correlated closely with serum T4 levels ( $\odot$ Fig. 4) and thus strongly suggests that this Bridge Assay measures stimulation of thyroidal secretion by TRAb very effectively. This is supported by the generally acknowledged opinion that thyroid stimulating immunoglobulins bind at the N-terminal part of the TSHR ECD, although it is not excluded that some of the rare blocking autoantibodies are binding at the $\mathrm{N}$-terminus and are thus recognized by our Bridge Assay. Nevertheless, the Bridge Assay will permit new, detailed evaluation of GD patients both at presentation and throughout their management. Finally, the robustness of the Bridge Assay may enable high throughput by performance on automated platforms.

\section{Acknowledgements}

We thank Dr. D. B. Ramsden and Prof. Dr. K. H. Jakobs for the help in the preparation of the manuscript. We also thank Dr. B. Rapoport for providing the cDNA for hTSHR and Dr. D. L. Segaloff for providing the pcDNA3-rLHR(B9) plasmid. We acknowledge grate- 
fully the Endokrinologie und Diabetologie, Stuttgart, Germany (Prof. Dr. M. Grußendorf) and Ito Hospital, Tokyo (Dr.J. Yoshimura Noh, Dr. Y. Kunii) for providing sera and corresponding TRAbvalues.

\section{Conflict of Interest}

Ulrich Loos is co-owner of KreLo GmbH Medical Diagnostics. Sigrid Bräth is employee at KreLo GmbH Medical Diagnostics. Claudia Frank was employee at KreLo GmbH Medical Diagnostics until 2013. KreLo GmbH Medical Diagnostics has a cooperation agreement with Siemens Healthcare Diagnostics.

\section{References}

1 Weetman AP. Graves' disease. N Engl J Med 2000; 343: 1236-1248

2 Prabhakar BS, Bahn RS, Smith TJ. Current perspective of the pathogenesis of Graves' disease and ophthalmopathy. Endocr Rev 2003; 24: 802-835

3 Bartalena L. Diagnosis and management of Graves' disease: a global overview. Nat Rev Endocrinol 2013; 9: 724-734

4 Jameson JL. Endocrinology and metabolism. In: Fauci A, Braunwald E, Kasper D, Hauser S, Longo D, Jameson J, Loscalzo J (eds.). Harrison's Prinicples of Internal Medicine. $17^{\text {th }}$ edition New York: McGraw Hill, 2008; 2233

5 Abraham-Nordling $M$, Byström $K$, Törring O, Lantz M, Berg G, Calissendorff J, Nyström HF, Jansson S, Jörneskog G, Karlsson FA, Nyström E, Ohrling $H$, Orn $T$, Hallengren $B$, Wallin $G$. Incidence of hyperthyroidism in Sweden. Eur J Endocrinol 2011; 165: 899-905

6 Johns Hopkins Medical Institutions. Autoimmune Disease Research Center. Information on Graves' disease. Available at http://autoimmune.pathology.jhmi.edu/diseases.cfm? systemID = 3\&diseaseID = 21 Accessed 18 July 2014

7 Shewring G, Smith BR. An improved radioreceptor assay for TSH receptor antibodies. Clin Endocrinol (Oxf) 1982; 17: 409-417

8 Costagliola S, Morgenthaler NG, Hoermann R, Badenhoop K, Struck J, Freitag D, Poertl S, Weglöhner W, Hollidt JM, Quadbeck B, Dumont JE, Schumm-Draeger PM, Bergmann A, Mann K, Vassart G, Usadel KH. Second generation assay for thyrotropin receptor antibodies has superior diagnostic sensitivity for Graves' disease. J Clin Endocrinol Metab 1999; 84: 90-97

9 Gassner D, Stock W, Golla R, Roth HJ. First automated assay for thyrotropin receptor autoantibodies. Clin Chem Lab Med 2009; 47: 1091-1095

10 Vitti P, Valente WA, Ambesi-Impiombato FS, Fenzi GF, Pinchera A, Kohn $L D$. Graves' IgG stimulation of continuously cultured rat thyroid cells: a sensitive and potentially useful clinical assay. J Endocrinol Invest 1982; 5: 179-182

11 Giuliani C, Cerrone D, Harii N, Thornton M, Kohn LD, Dagia NM, Fiore E, Bucci I, Chamblin T, Vitti P, Monaco F, Napolitano G. A TSHr-LH/ CGr chimera that measures functional TSAb in Graves' disease. J Clin Endocrinol Metab 2012; 97: E1106-E1115

12 Lytton SD, Ponto KA, Kanitz M, Matheis N, Kohn LD, Kahaly GJ. A novel thyroid stimulating immunoglobulin bioassay is a functional indicator of activity and severity of Graves' orbitopathy. J Clin Endocrinol Metab 2010; 95: 2123-2131

13 Diana T, Kanitz M, Lehmann M, Li Y, Olivo PD, Kahaly GJ. Standardization of a bioassay for thyrotropin receptor stimulating autoantibodies. Thyroid 2015; 25: 169-175

14 Araki N, Iida M, Amino N, Morito S, Ide A, Nishihara E, Ito M, Saito J, Nishikawa T, Katsuragi K, Miyauchi A. Rapid bioassay for the detection of thyroid-stimulating antibodies using cyclic adenosine monophosphate-gated calcium channel and aequorin. Eur Thyroid J 2014; 4: 14-19

15 Minich WB, Loos $U$. Isolation of radiochemically pure ${ }^{125}$ I-labeled human thyrotropin receptor and its use for the detection of pathological autoantibodies in sera from Graves' patients. J Endocrinol 1999; 160: 239-245

16 Minich WB, Loos $U$. Detection of functionally different types of pathological autoantibodies against thyrotropin receptor in Graves' patients sera by luminescent immunoprecipitation analysis. Exp Clin Endocrinol Diabetes 2000; 108: 110-119

17 Chazenbalk GD, Pichurin P, McLachlan SM, Rapoport B. A direct binding assay for thyrotropin receptor autoantibodies. Thyroid 1999; 9: 1057-1061
18 Sanders J, Oda Y, Roberts S, Kiddie A, Richards T, Bolton J, McGrath V, Walters S, Jaskólski D, Furmaniak J, Smith BR. The interaction of TSH receptor autoantibodies with 125I-labelled TSH receptor. J Clin Endocrinol Metab 1999; 84: 3797-3802

19 Loos U, Franz C, Minich WB, Büsselmann I. Direct assay of TSH receptor autoantibodies causing Graves' disease correlates with the clinical diagnosis closer than assays on TSH displacement. Horm Res 2007; 68 (Suppl 3): 21-29

20 Rees Smith B, Sanders J, Evans M, Tagami T, Furmaniak J. TSH receptorautoantibody interactions. Horm Metab Res 2009; 41: 448-455

21 Tahara K, Ishikawa N, Yamamoto K, Hirai A, Ito K, Tamura Y, Yoshida S, Saito Y, Kohn LD. Epitopes for thyroid stimulating and blocking autoantibodies on the extracellular domain of the human thyrotropin receptor. Thyroid 1997; 7: 867-877

22 Rapoport B, Chazenbalk GD, Jaume JC, McLachlan SM. The thyrotropin (TSH) receptor: interaction with TSH and autoantibodies. Endocr Rev 1998; 19: 673-716

23 Tahara K, Ban T, Minegishi T, Kohn LD. Immunoglobins from Graves' disease patients interact with different sites on TSH receptor/LH-CG receptor chimeras then either TSH or immunoglobins from idiopathic myxedema patients. Biochem Biophys Res Commun 1991; 179: 70-77

24 McFarland KC, Sprengel R, Phillips HS, Köhler M, Rosemblit N, Nikolics $K$, Segaloff DL, Seeburg PH. Lutropin-choriogonadotropin receptor: an unusual member of the $G$ protein-coupled receptor family. Science 1989; 245: 494-499

25 Loos U, Schmitt T, Frank C, Büsselmann I. Development of a novel bioassay for the detection of thyroid-stimulating autoantibodies in Graves' disease (GD) facilitating routine measurement by reduced handling steps and high stability of cAMP monitoring reagent. Poster presentation at the ITC Paris 2010; P-0020 Available at https://b-com.mcigroup.com/AbstractList/ITC2010.aspx

26 Bahn RS, Burch HB, Cooper DS, Garber JR, Greenlee MC, Klein I, Laurberg P, McDougall IR, Montori VM, Rivkees SA, Ross DS, Sosa JA, Stan MN. American Thyroid Association; American Association of Clinical Endocrinologists. Hyperthyroidism and other causes of thyrotoxicosis: management guidelines of the American thyroid association and American association of clinical endocrinologists. Endocr Pract 2011; 17: e1-e65

27 European Group on Graves' Orbitopathy (EUGOGO). Wiersinga WM, Perros P, Kahaly GJ, Mourits MP, Baldeschi L, Boboridis K, Boschi A, Dickinson AJ, Kendall-Taylor P, Krassas GE, Lane CM, Lazarus JH, Marcocci C, Marino M, Nardi M, Neoh C, Orgiazzi J, Pinchera A, Pitz S, Prummel MF, Sartini MS, Stahl M, von Arx G. Clinical assessment of patients with Graves' orbitopathy: the EUGOGO recommendations to generalists, specialists and clinical researchers. Eur J Endocrinol 2006; 155: 387-389

28 NCCLS document EP5-A. Evaluation of precision performance of clinical chemistry devices; approved guideline. Wayne PA: Clinical and Laboratory Standards Institute, 1999

$29 \mathrm{R}$ development core team, 2009. $\mathrm{R}$ : A language and environment for statistical computing; R foundation for statistical computing; Vienna, Austria. Availabvle at http://R-project.org

30 Morgenthaler NG, Minich WB, Willnich M, Bogusch T, Hollidt JM Weglohner $W$, Lenzner C, Bergmann A. Affinity purification and diagnostic use of TSH receptor autoantibodies from human serum. Mol Cell Endocrinol 2003; 212: 73-79

31 Nakatake N, Sanders J, Richards T, Burne P, Barrett C, Dal Ora C, Presotto F, Betterle C, Furmaniak J, Rees Smith B. Estimation of serum TSH receptor autoantibody concentration and affinity. Thyroid 2006; 16: $1077-1084$

32 Bahn R, Levy E, Wartofsky L. Graves' disease. J Clin Endocrinol Metab 2007; 92: 2p following 14A

33 Eckstein A, Plicht M, Lax H, Neuhäuser M, Mann K, Lederbogen S, Heckmann C, Esser J, Morgenthaler NG. Thyrotropin receptor autoantibodies are independent risk factors for Graves' ophtalmopathy and help to predict severity and outcome of the disease. J Clin Endocrinol Metab 2006; 91: 3464-3470

34 Evans M, Sanders J, Tagami T, Sanders P, Young S, Roberts E, Wilmot J, Hu X, Kabelis K, Clark J, Holl S, Richards T, Collyer A, FurmaniakJ, Smith BR. Monoclonal autoantibodies to the TSH receptor, one with stimulating activity and one with blocking activity, obtained from the same blood sample. Clin Endocrinol 2010; 73: 404-412

35 Sanders $P$, Young S, Sanders J, Kabelis K, Baker S, Sullivan A, Evans $M$ Clark J, Wilmot J, Hu X, Roberts E, Powell M, Nunez Miguel R, Furmaniak $J$, Smith BR. Crystal structure of the TSH receptor (TSHR) bound to a blocking-type TSHR autoantibody. J Mol Endocrinol 2011; 46: 81-99 
36 Li Y, Kim J, Diana T, Klasen R, Olivo PD, Kahaly GJ. A novel bioassay for anti-thyrotropin autoantibodies detects both thyroid-blocking and stimulating activity. Clin Exp Immunol 2013; 173: 390-397

37 Minich WB, Lenzner C, Bergmann A, Morgenthaler NG. A coated tube assay for the detection of blocking thyrotropin receptor autoantibodies. J Clin Endocrinol Metab 2004; 89: 352-356

38 Grasso Y, Kim MR, Faiman C, Kohn LD, Tahara K, Gupta MK. Epitope heterogeneity of thyrotropin receptor-blocking antibodies in Graves' patients as detected with wild-type versus chimeric thyrotropin receptors. Thyroid 1999; 9: 531-537

39 Morgenthaler NG, Ho SC, Minich WB. Stimulating and Blocking Thyroid-Stimulating Hormone (TSH) Receptor Autoantibodies from patients with Graves' disease and autoimmune hypothyroidism have very similar concentration, TSH receptor affinity, and binding sites. J Clin Endocrinol Metab 2007; 92: 1058-1065

40 Ando T, Latif R, Daniel S, Eguchi K, Davies T. Dissecting linear and conformational epitopes on the native thyrotropin receptor. Endocrinology 2004; 14: 5185-5193

41 Giuliani C, Cerrone D, Harii N, Thornton M, Kohn LD, Dagia NM, Bucci I, Carpentieri M, Di Nenno B, Di Blasio A, Vitti P, Monaco F, Napolitano G. A TSHR-LH/CGR chimera that measures functional thyroid-stimulating autoantibodies (TSAb) can predict remission or recurrence in Graves' patients undergoing antithyroid drug (ATD) treatment. J Clin Endocrinol Metab 2012; 97: E1080-E1087
42 Zöphel K, Grüning T, Roggenbuck D, Wunderlich G, Kotzerke J. On specificity of $2^{\text {nd }}$ generation TSH receptor autoantibody measurements. Clin Lab 2008; 54: 243-249

43 Schott M, Morgenthaler NG, Fritzen R, Feldkamp J, Willenberg HS, Scherbaum WA, Seissler J. Levels of autoantibodies against human TSH receptor predict relapse of hyperthyroidism in Graves' disease. Horm Metab Res 2004; 36: 92-96

44 Eckstein A, Mann K, Kahaly GJ, Grussendorf M, Reiners C, Feldkamp J, Quadbeck B, Bockisch A, Schott M. Role of TSH receptor autoantibodies for the diagnosis of Graves' disease and for the prediction of the course of hyperthyroidism and ophtalmopathy. Recommendations of the Thyroid Section of the German Society of Endocrinology. Med Klin (Munich) 2009; 104: 343-348

45 Carella C, Mazziotti G, Sorvillo F, Piscopo M, Cioffi M, Pilla P, Nersita $R$, Iorio $S$, Amato G, Braverman LE, Roti E. Serum thyrotropin receptor antibodies concentrations in patients with Graves' disease before, at the end of methimazole treatment, and after drug withdrawal: evidence that the activity of thyrotropin receptor antibody and/or thyroid response modify during the observation period. Thyroid 2006; 16: $295-302$ 